\title{
THE EFFECTIVENESS OF ZINC AND RISEDRONATE ON BONE TURNOVER IN RAT MODEL OF OSTEOPOROSIS ASSESSED WITH THE EXPRESSION OF $\beta$ - CROSSLAPS
}

\author{
Adam Fajar ${ }^{*}$, Mohammad Rizal Chaidir², Dicky Mulyadi², Ahmad Ramdan², Yoyos \\ Dias Ismiarto ${ }^{3 *}$ \\ ${ }^{1}$ Resident of Orthopaedic and Traumatology Department, Faculty of Medicine Universitas \\ Padjadjaran/Dr. Hasan Sadikin General Hospital, Bandung \\ ${ }^{2}$ Staff of Orthopaedics and Traumatology Department, Faculty of Medicine Universitas \\ Padjadjaran/Dr. Hasan Sadikin Hospital, Bandung \\ ${ }^{3}$ Head of Study Program of Orthopaedics and Traumatology Department, Faculty of \\ Medicine Universitas Padjadjaran/Dr. Hasan Sadikin Hospital, Bandung
}

*Corresponding Author: Yoyos Dias Ismiarto, Head of Study Program of Orthopaedics and Traumatology Department, Faculty of Medicine Universitas Padjadjaran/Dr. Hasan Sadikin Hospital, Bandung, Jl. Pasteur No. 38, Jawa Barat 4016, Telp : (022) 2035477

Email: adam_fajar@yahoo.com.sg

\begin{abstract}
ABSTRAK
Latar Belakang: Angka kejadian osteoporosis di Indonesia masih tinggi. Risedronate merupakan bifosfonat yang sering digunakan. Namun, pemberian jangka panjang dapat menimbulkan efek samping berbahaya bagi pasien. Penelitian sebelumnya pada tikus model osteoporosis, Zink terbukti memiliki potensi dalam pencegahan dan pengembalian struktur tulang dengan menstimulasi osteoblas dalam proses pembentukan tulang dan menghambat aktivitasosteoklas dalam meresorpsi tulang, dengan cara meningkatkan produksi Osteoprotegerin yang menghambat ikatan antara RANKL dan RANK.

Tujuan: Untuk mengetahui efektivitas Zink dan Risedronate terhadap bone turnover pada tikus model osteoporosis yang dinilai menggunakan ekspresi $\beta$-CrossLaps.

Metodologi: Penelitian ini merupakan penelitian uji eksperimental menggunakan 25 tikus Galur Wistar betina yang dibagi menjadi kelompok Non-Ovariektomi dan Ovariektomi untuk menginduksi terjadinya osteoporosis. Pemberian perlakuan dibedakan menjadi ZinkRisedronate, Zink, dan Risedronate. One Way Anova dan T-test tidak berpasangan digunakan untuk mengetahui adanya kemaknaan secara statistik.

Hasil: Hasil uji statistika One Way Anova, menunjukkan bahwa ekspresi $\beta$-CrossLaps pada pengambilan ke-3 memiliki nilai $\mathrm{p}$ lebih kecil dari 0,05 (nilai $\mathrm{p}<0,05$ ), yang menunjukkan adanya perbedaan rerata yang signifikan secara statistik antara variabel pada semua kelompok. Selanjutnya, hasil uji statistika menggunakan T-test tidak berpasangan, menunjukkan bahwa perbandingan ekspresi $\beta$-CrossLaps pada pengambilan ke-3 terhadap kelompok Ovari dengan Ovari+Zink, dan Ovari dengan Ovari+Zink+Rise memiliki nilai $\mathrm{p}$ lebih kecil dari 0,05 (nilai $\mathrm{p}<0,05$ ), yang menunjukkan bahwa terdapat perbedaan rerata yang signifikan secara statistik antara kedua kelompok tersebut.
\end{abstract}

Kesimpulan: Pemberian Zink-Risedronate lebih menurunkan bone turnover dan ekspresi $\beta$ CrossLap dibandingkan dengan Zink atau Risedronate saja pada tikus model osteoporosis.

Kata Kunci : Osteoporosis, Risedronate, Zink, $\beta$-CrossLaps

\section{ABSTRACT}

Background: Osteoporosis prevalence in Indonesia is high. Risedronate commonly used for treating the osteoporosis. Unfortunately, long term therapy can cause hazardous adverse effect to the patient. Previous research in rat model osteoporosis, Zinc have a potential effect to prevent and rebuild bone structure with osteoblast stimulation in bone formation and 
Artikel Penelitian

Vol 7 No. 2, Oktober 2018

ISSN 2460-8742

http://journal.unair.ac.id/ORTHO@journal-orthopaedi-and-traumatology-surabaya-media-104.htmI

osteoclast activity inhibition in bone resorption by increasing Osteoprotegerin production, that inhibit bond between RANKL and RANK.

Purpose: To determine the effectiveness of Zink and Risedronate on bone turnover in osteoporotic model rats assessed the $\beta$-CrossLaps expression.

Methods: This research is conducted as experimental comparative method used 25 female Galur Wistar rat that divided into Non-ovariectomy and Ovariectomy group to induce osteoporosis. The treatment is divided into Zinc-Risedronate, and Zinc, or Risedronate only. One Way Anova and Independent T-test was used to analyzed the significant difference between groups.

Result: One Way Anova statistic test for $\beta$-CrossLaps expression value in the 3rd Taken blood sample showed that $\mathrm{p}$ is less than $0.05(\mathrm{p}<0.05)$, which indicated that are significant difference in the mean between variable at 3rd Taken blood sample in all group. Meanwhile, Independent T-test was used to compare $\beta$-CrossLaps expression in 3rd taken blood sample between Ovari and Ovari+Zinc, Ovari and Ovari+Zinc+Rise showed $\mathrm{p}$ is less than 0.05 $(\mathrm{p}<0.05)$, which indicated that there are significant difference in the mean between variable 2 groups.

Conclusion: Zinc-Risedronate administration will decrease bone turnover and $\beta$-CrossLaps expression more than Zinc or Risedronate only in rat model osteoporosis.

Keyword: Osteoporosis, Risedronate, Zink, $\beta$-CrossLaps

\section{PENDAHULUAN}

Osteoporosis ditandai dengan adanya pengurangan massa tulang dan gangguan mikro-arsitektur jaringan tulang, yang mengakibatkan tulang menjadi rapuh dan meningkatkan risiko fraktur. Hilangnya massa tulang terjadi dengan seiringnya bertambahnya usia. Pada wanita hal ini secara langsung berkaitan dengan fungsi ovarium, sehingga pencegahan terhadap komplikasi, menjadi salah satu tujuan penatalaksanaan. ${ }^{1}$ Masalah usia lanjut dan osteoporosis semakin menjadi perhatian dunia, termasuk Indonesia. Hal ini dilatarbelakangi oleh meningkatnya usia harapan hidup. Keadaan ini menyebabkan peningkatan penyakit menua yang menyertainya, antara lain osteoporosis. Berdasarkan penelitian Bone Mineral Density (BMD) yang dilakukan pada tahun
2006 di Indonesia, prevalensi osteoporosis pada wanita usia 50-80 tahun adalah sebesar 23\% dan 70-80 tahun sebesar $53 \% .^{2}$

Secara umum penyebab dari osteoporosis adalah ketidakseimbangan pada bone remodeling, yakni aktivitas resorpsi oleh osteoklas lebih tinggi dibandingkan dengan aktivitas formasi oleh osteoblas. Pada wanita, defisiensi estrogen yang terjadi selama masa perimenopausal dan postmenopausal akan menyebabkan peningkatan produksi RANKL, yang akhirnya mempercepat proses kehilangan kepadatan tulang. ${ }^{3,4}$

Bifosfonat merupakan obat yang paling umum digunakan untuk pengobatan osteoporosis. Namun, penggunaan obatobat ini dalam jangka waktu lama pun 
Artikel Penelitian

Vol 7 No. 2, Oktober 2018

ISSN 2460-8742

http://journal.unair.ac.id/ORTHO@journal-orthopaedi-and-traumatology-surabaya-media-104.htmI

memiliki beberapa efek samping yang dapat membahayakan pasien, diantaranya osteonecrosis of the jaw (ONJ), atypical subtrochanteric and diaphyseal femur fractures (AFF). Risedronate merupakan Nitrogen-containing bisphosphonates (NBPs). Efek anti resorpsi pada risedronate merupakan hasil kemampuannya dalam menghambat enzim Farnesil Pirofosfat Sintase (FPPS) pada level osteoklastik. Risedronate terdistribusi secara luas di tulang karena tidak berikatan kuat dengan mineral, sehingga memiliki waktu paruh sampai dengan berminggu-minggu. Hal ini menyebabkan efek inhibisi bone turnover yang kuat selama pemberian jangka panjang dan menetap walaupun terapi dihentikan. Risedronate mampu menurunkan bone turnover hingga 50\%, akan kembali seperti semula setelah 12 bulan terapi dihentikan. ${ }^{4-6}$

Osteogenesis adalah suatu proses pembentukan tulang yang terdiri dari 3 tahapan utama, yaitu: 1) produksi matriks organik ekstraseluler (osteoid); 2) mineralisasi matriks untuk membentuk tulang; dan 3) bone remodeling oleh aktivitas resorpsi dan deposisi. Aktivitas seluler dari osteoblas, osteoklas dan osteosit diperlukan pada proses ini. Zink diketahui memiliki peran penting dalam regulasi aktivitas selular sebagai kofaktor yang menstimulasi protein sintesis yang diperlukan dalam pembentukan matriks organik (produksi kolagen). Matriks organik tulang mengandung 90\%-95\% kolagen yang akan membentuk kerangka struktural dimana mineralisasi akan terjadi. Komponen mineral utama dari tulang adalah garam kristalin yang terbuat dari kalsium hidrosiapatit $\left(\mathrm{Ca}_{10}\left(\mathrm{PO}_{4}\right)_{6}(\mathrm{OH})_{2}\right)$. Kristal hidroksiapatit juga mengandung zink dan metal transisi lainnya. Zink juga berfungsi sebagai komponen metal dari alkalin fosfatase, yaitu suatu metaloenzym yang berperan dalam pembentukan tulang baru. Satu molekul alkalin fosfatase mengandung 4 atom zink, yakni dua atom zink sangat penting untuk aktivitas enzim tersebut. Zink dapat mempengaruhi peningkatan alkaline fosfatease-related DNA synthesis yang dapat menstimulasi pertumbuhan tulang. Terdapat penelitian yang menyatakan bahwa pemberian suplementasi zink memiliki efek stimulasi langsung pada alkaline fosfatase dan ostecalcin.

Zink juga berperan dalam mengatur aktivitas sel yang terlibat dalam pembentukan kerangka tulang. Secara umum, zink meningkatkan sintesis insulin like growth factor 1 (IGF-1) dan efeknya pada jaringan. Zink juga menstimulasi proliferasi dan diferensiasi osteoblas melalui mekanisme yang mempengaruhi aktivitas calcium-regulating hormon 1, 24- 
Artikel Penelitian

Vol 7 No. 2, Oktober 2018

ISSN 2460-8742

http://journal.unair.ac.id/ORTHO@journal-orthopaedi-and-traumatology-surabaya-media-104.html

vitamin $\mathrm{D}$ dan hormon paratiroid $(\mathrm{PTH})$.

Zink juga menghambat PTH-induced bone resorption. Zink dibutuhkan dalam aktivitas osteoblas, Aminoacyl-tRNAsynthetase yang terdapat didalam osteoblas diaktifkan oleh zink.

Zink berperan sebagai regulator lokal pada fungsi osteoblas dan osteoklas. Secara in vitro, zink akan menstimulasi produksi TGF- $\beta$ pada osteoblas. TGF- $\beta$ berfungsi sebagai coupling factor pada proses pembentukan dan resorpsi tulang. TGF- $\beta$ memiliki efek stimulasi dan inhibisi pada pembentukan osteoclast-like cell, dan zink dapat menghambat efek stimulasi dari TGF- $\beta$ tersebut.

Zink memiliki efek inhibisi terhadap resorpsi tulang dengan cara mencegah aktivitas osteoklas, mekanisme terjadinya hal ini belum sepenuhnya diketahui. Selain itu, zink juga menghambat aktivitas hormon paratiroid dan prostaglandin $E_{2}$, sehingga akan menghambat pembentukan osteoclast-like cell. Secara tidak langsung, zink menghambat RANKL-stimulated osteoclastogenesis dengan cara menekan jaras sinyal yang dibutuhkan dalam stimulasi RANKL untuk perkembangan dan diferensiasi sel osteoklas.

OPG adalah faktor pertama yang ditemukan untuk meregulasi diferensiasi osteoklas. Pre-osteoblas akan mengekspre- sikan RANKL dalam jumlah besar dibandingkan dengan OPG, dimana RANKL ini akan menstimulasi diferensiasi dan fungsi osteoklas. Osteoblas dewasa akan mengekspresikan OPG yang lebih besar dibandingkan dengan RANKL yang akan menghambat diferensiasi dan fungsi dari osteoklas. Pada tulang yang sehat, OPG berfungsi untuk menjaga keseimbangan antara resorpsi dan formasi. OPG berperan sebagai reseptor tipuan (decoy receptor) untuk mencegah RANKL berikatan dengan reseptornya, atau menetralisir aktivitas RANKL. Dengan keberadaan zink pada sel osteoblas, akan menstimulasi TGF- $\beta$ yang selanjutnya akan meningkatkan produksi OPG, yakni OPG akan berikatan dengan RANKL dan mencegah interaksinya dengan RANK, sehingga akan menghambat pembentukan dan aktivasi osteoklas.

Penelitian yang dilakukan dengan cara memberikan genistein, isoflavone dan zink secara oral kepada model hewan osteoporosis menunjukan bahwa zink saling bersinergis dalam mencegah hilangnya massa tulang. ${ }^{3,7,8}$

Saat ini telah dikembangkan pemeriksan $\beta$-CrossLaps yang dapat digunakan sebagai marker resorpsi tulang yang sensitif dan spesifik. $\beta$-Crosslap merupakan pemeriksaan kuantitatif untuk mengukur kadar resorpsi tulang dalam 


\section{Artikel Penelitian}

Vol 7 No. 2, Oktober 2018

ISSN 2460-8742

http://journal.unair.ac.id/ORTHO@journal-orthopaedi-and-traumatology-surabaya-media-104.html

serum, plasma atau cairan biologis lainnya.

Sensitivitas mencapai $>70 \%$ karena memiliki Detection Range yang sangat luas dan spesifisitas $80 \%$, karena tidak adanya reaktivitas silang dan pengaruh dari protein antibodi analog $\beta$-CrossLap lain. $\beta$ CrossLaps adalah hasil pemecahan protein kolagen tipe 1 yang spesifik tulang dan merupakan produk metabolisme tulang secara langsung. Metabolisme tulang yang dilakukan oleh osteoklas akan menghancurkan kolagen tipe 1 dan terbentuk bentuk $\alpha$ dan $\beta$. Bentuk $\beta$ ini disebut $\beta$-CrossLaps dan kadarnya dapat diukur dari serum, plasma atau urin..$^{9-11}$

\section{METODOLOGI PENELITIAN}

Objek penelitian ini adalah tikus galur Wistar betina umur lebih dari 9 minggu dengan berat badan rata-rata 250290 gram. Penelitian ini telah mendapatkan Persetujuan Penelitian dari Komite Etik Penelitian Kesehatan Rumah Sakit Umum Pusat Dr. Hasan Sadikin Bandung dengan No Surat : LB.04.01/A05/EC/043/II/2017 dengan periode penelitian April sampai dengan Juni 2017.

Kriteria inklusi pada penelitian ini yaitu, tikus dalam keadaan sehat untuk dilakukan tindakan ovariektomi, sedangkan kriteria ekslusi yaitu, adanya perubahan perilaku pada tikus (tidak mau bergerak, infeksi). Berdasarkan rumus Federer, jumlah sampel yang dibutuhkan pada penelitian ini adalah 5 tiap kelompok penelitian. Sebanyak 10-20\% ditambahkan sebagai sample dropout.

Bahan yang digunakan pada penelitian ini yaitu, larutan Zinc (ZincPro; Zinc sulphate sirup $20 \mathrm{mg} / 5 \mathrm{~mL}$, Combiphar), Risedronate (Osteonate; Risedronate sodium $5 \mathrm{mg}$ Kalbe), Dexamethasone injeksi (Dexamethasone 0,5 mg, Phapros). Sedangkan alat yang digunakan dalam penelitian ini yaitu mouse $\beta$-CrossLaps ELISA kit (Korain Biotech,China) dan Microplate Reader Rayto RT-6500 (Shenzhen, China). 
Artikel Penelitian

Vol 7 No. 2, Oktober 2018

ISSN 2460-8742

http://journal.unair.ac.id/ORTHO@journal-orthopaedi-and-traumatology-surabaya-media-104.htmI

Tabel 1. Nilai Ekspresi $\beta$-CrossLaps untuk semua sampel

\begin{tabular}{|c|c|c|c|c|}
\hline Kelompok & Sampel & $\begin{array}{c}\text { Pengambilan } \\
\text { ke-1 }\end{array}$ & $\begin{array}{c}\text { Pengambilan } \\
\text { ke-2 }\end{array}$ & $\begin{array}{c}\text { Pengambilan } \\
\text { ke-3 }\end{array}$ \\
\hline \multirow{5}{*}{$\begin{array}{c}\text { Kontrol } 0 \\
\text { (Non- } \\
\text { Ovari) }\end{array}$} & 1 & 6,376 & 6,532 & 6,965 \\
\hline & 2 & 6,731 & 7,023 & 8,193 \\
\hline & 3 & 4,631 & 4,654 & 4,281 \\
\hline & 4 & 5,488 & 5,242 & 5,313 \\
\hline & 5 & 4,906 & 5,246 & 5,388 \\
\hline \multirow{5}{*}{$\begin{array}{c}\text { Kontrol } 1 \\
\text { (Ovari) }\end{array}$} & 6 & 3,651 & 4,955 & 5,747 \\
\hline & 7 & 6,022 & 6,251 & 8,083 \\
\hline & 8 & 7,256 & 8,294 & 8,334 \\
\hline & 9 & 7,293 & 10,394 & 12,238 \\
\hline & 10 & 3,901 & 5,919 & 6,889 \\
\hline \multirow{5}{*}{$\begin{array}{c}\text { Treatment } \\
1 \\
\text { (Ovari + } \\
\text { Zink }\end{array}$} & 11 & 6,431 & 8,783 & 5,129 \\
\hline & 12 & 5,588 & 4,879 & 5,751 \\
\hline & 13 & 5,412 & 6,371 & 4,236 \\
\hline & 14 & 5,088 & 6,073 & 6,605 \\
\hline & 15 & 3,924 & 6,772 & 6,014 \\
\hline \multirow{5}{*}{$\begin{array}{c}\text { Treatment } \\
2 \\
\text { (Ovari + } \\
\text { Rise) }\end{array}$} & 16 & 3,610 & 4,938 & 5,921 \\
\hline & 17 & 6,793 & 6,367 & 7,161 \\
\hline & 18 & 5,593 & 6,976 & 8,413 \\
\hline & 19 & 8,241 & 9,128 & 5,276 \\
\hline & 20 & 4,026 & 6,338 & 4,637 \\
\hline \multirow{5}{*}{$\begin{array}{c}\text { Treatment } \\
3 \\
\text { (Ovari + } \\
\text { Zink + } \\
\text { Rise) }\end{array}$} & 21 & 4,661 & 6,056 & 4,556 \\
\hline & 22 & 4,212 & 4,509 & 6,567 \\
\hline & 23 & 4,319 & 6,748 & 4,167 \\
\hline & 24 & 6,418 & 7,981 & 3,679 \\
\hline & 25 & 6,315 & 6,913 & 4,016 \\
\hline
\end{tabular}

Simple Randomization Sampling digunakan untuk membagi keseluruhan sampel kedalam 5 kelompok penelitian yaitu:

1) Kelompok yang tidak mendapat perlakuan ovariektomi dan tidak diberikan injeksi dexamethasone, Zink atau Risedronate, serta diinkubasi selama 2 bulan.

2) Kelompok ovariektomi (Gambar 1) adalah kelompok yang mendapat perlakuan ovariektomi dan injeksi dexamethasone dengan dosis 0,3 $\mathrm{mg} / \mathrm{kgBB}$ atau $0,02 \mathrm{~mL} / \mathrm{ming} g u$ tiap minggu selama 2 bulan. Kelompok ini dibagi menjadi empatbagian, yaitu sebagai berikut ${ }^{12-15}$ :

a. Kelompok yang mendapat perlakuan ovariektomi dan injeksi dexamethasone selama satu bulan, tanpa diberikan Zink atau Risedronate selama 1 bulan.

b. Kelompok yang mendapat perlakuan ovariektomi dan injeksi dexamethasone selama satu bulan, kemudian diikuti dengan pemberian zink $1 \mathrm{x}$ tiap hari pada pagi hari dengan dosis $10 \mathrm{mg} / \mathrm{kgBB} /$ hari atau $0,75 \mathrm{~mL} /$ hari selama 1 bulan.

c. Kelompok yang mendapat perlakuan ovariektomi dan injeksi dexamethasone selama satu bulan, kemudian diikuti dengan pemberian Risedronate $1 \mathrm{x} /$ minggu dengan dosis $35 \mu \mathrm{g} / \mathrm{kgBB} / \mathrm{minggu} 0,05 \mathrm{~mL} / \mathrm{minggu}$ selama 1 bulan.

d. Kelompok yang mendapat perlakuan ovariektomi dan injeksi dexamethasone selama satu bulan, kemudian diikuti dengan pemberian zink $1 \mathrm{x}$ tiap hari pada pagi hari dengan dosis $10 \mathrm{mg} / \mathrm{kgBB} / \mathrm{hari}$ dan risedronate $1 \mathrm{x} /$ minggu dengan dosis $35 \mu \mathrm{g} / \mathrm{kgBB} /$ minggu selama 1 bulan. 
Artikel Penelitian

Vol 7 No. 2, Oktober 2018

ISSN 2460-8742

http://journal.unair.ac.id/ORTHO@journal-orthopaedi-and-traumatology-surabaya-media-104.html

Tabel 2. Uji One Way ANOVA

\begin{tabular}{|c|c|c|c|c|c|c|}
\hline \multirow[b]{2}{*}{ Variabel } & \multicolumn{5}{|c|}{ Kelompok } & \multirow[t]{2}{*}{ Nilai $\mathbf{P}$} \\
\hline & $\begin{array}{c}\text { Non Ovari } \\
\quad \mathrm{N}=5\end{array}$ & $\begin{array}{c}\text { Ovari } \\
\mathrm{N}=5\end{array}$ & $\begin{array}{c}\text { Ovari+Zink } \\
\mathrm{N}=5\end{array}$ & $\begin{array}{c}\text { Ovari+ } \\
\text { Rise } \\
\text { N=5 }\end{array}$ & $\begin{array}{c}\text { Ovari+Zink } \\
\quad+\text { Rise } \\
\quad \mathrm{N}=5\end{array}$ & \\
\hline \multicolumn{6}{|c|}{ Pengambilan ke-2 } & 0,682 \\
\hline Mean \pm STD & $5,73 \pm 0,993$ & $7,16 \pm 2,177$ & $6,57 \pm 1,421$ & $6,74 \pm 1,525$ & $6,44 \pm 1,281$ & \\
\hline Median & 5,246 & 6,251 & 6,371 & 6,367 & 6,748 & \\
\hline $\begin{array}{l}\text { Range (min- } \\
\operatorname{max)}\end{array}$ & $4,65-7,02$ & $4,96-10,39$ & $4,88-8,78$ & $4,94-9,13$ & $4,51-7,98$ & \\
\hline \multicolumn{6}{|c|}{ Pengambilan ke-3 } & $0,024 * *$ \\
\hline Mean \pm STD & $6,02 \pm 1,544$ & $8,25 \pm 2,452$ & $5,54 \pm 0,904$ & $6,28 \pm 1,513$ & $4,59 \pm 1,145$ & \\
\hline Median & 5,388 & 8,083 & 5,751 & 5,921 & 4,167 & \\
\hline $\begin{array}{l}\text { Range (min- } \\
\operatorname{max)}\end{array}$ & $4,28-8,19$ & $5,75-12,24$ & $4,24-6,61$ & $4,64-8,41$ & $3,68-6,57$ & \\
\hline
\end{tabular}

Darah sampel dilakukan sebanyak 3 kali, yaitu saat awal penelitian; akhir bulan pertama (1 bulan setelah ovariektomi); dan akhir bulan kedua (1 bulan setelah perlakuan). Pengambilan dua sampel darah awal dari ekor tikus, sedangkan pengambilan ke-3 dari jantung tikus. Tiap pengambilan sampel darah dimasukkan ke dalam tabung vakum (plain), pencatatan waktu dari mulai dimasukkan darah ke dalam tabung. Tabung pengambilan sampel merupakan tabung sekali pakai, nonpyrogenic, dan non-endotoxin. Selanjutnya, sampel dikirim dari Lab. farmakologi ke Lab. Patologi Klinik dengan menggunakan tas/boks dengan suhu ruangan. Kemudian disimpan dalam suhu $-80^{\circ} \mathrm{C}$.

Setelah semua sampel lengkap, sampel kemudian di keluarkan dari pendingin dan dibiarkan pada suhu ruangan, sampai dengan siap dilakukan pemeriksaan $\beta$-crossLaps ELISA kit yang menggunakan prinsip competitive enzymelinked immuno-sorbent assay. ${ }^{16}$

Analisis statistik digunakan untuk menilai proporsi kemaknaan setiap variabel menggunakan One Way Anova dan T-test tidak berpasangan pada program SPSS 23.
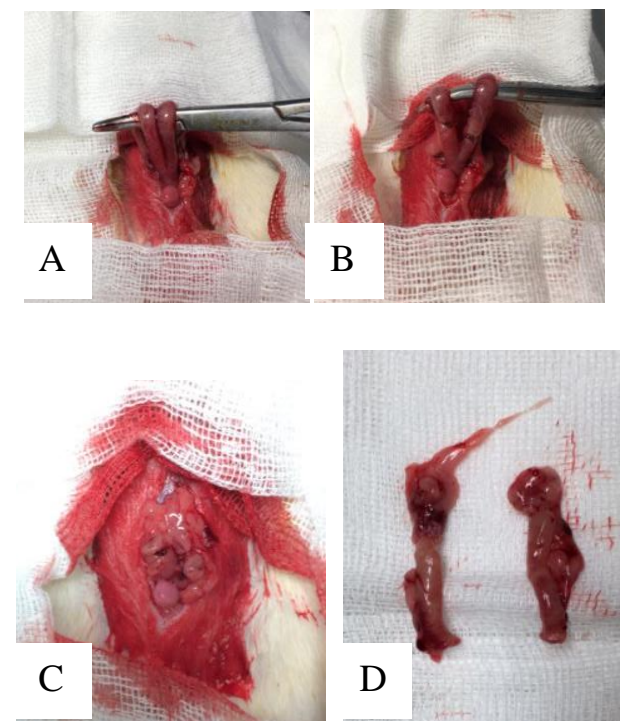

Gambar 1. Proses ovariektomi pada tikus. (A) Identifikasi ovari, (B) Ligasi ovari, (C) Ovari sudah dibuang, (D) Ovari tikus 
Artikel Penelitian

Vol 7 No. 2, Oktober 2018

ISSN $2460-8742$

http://journal.unair.ac.id/ORTHO@journal-orthopaedi-and-traumatology-surabaya-media-104.htmI

\section{HASIL DAN PEMBAHASAN}

Setelah 60 hari penelitian, perhitungan ekspresi $\beta$-crossLaps dilakukan pada 75 sampel (Tabel 1). Tidak terdapat efek samping terhadap hewan coba selama penelitian. Analisis statistik untuk data yang terdistribusi normal pada pengambilan ke-3 dan pengambilan ke-2 diuji menggunakan One Way Anova sehingga didapatkan nilai $\mathrm{p}=0,024 \quad(\mathrm{p}<0,05)$ yang menunjukan bahwa adanya perbedaan yang signifikan diantara kelompok setelah dan sebelum dilakukan perlakuan (pemberian Zink dan/atau Risedronate) seperti tampak pada Tabel 2.

Analisis statistik bagi data numerik yang terdistribusi secara normal pada Pengambilan sampel ke-3 diuji menggunakan $\mathrm{T}$ tidak berpasangan. Pada uji diantara kelompok Ovari dengan Ovari+Zink dan Ovari dengan Ovari+Zink+Risedronate didapatkan nilai $\mathrm{p}$ sebesar 0,049 dan 0,016 ( $\mathrm{p}<0,05)$. Hal ini menunjukkan adanya perbedaan yang signifikan atau bermakna secara statistik. Sedangkan, untuk kelompok ovari dan ovari+Risedronate didapatkan nilai p 0,164 $(\mathrm{p}>0,05)$, yang berarti tidak ada perbedaan Pengambilan ke-3
Mean \pm STD

Median Tabel 3. Uji $\mathrm{T}$ tidak berpasangan

\begin{tabular}{|c|c|c|c|}
\hline \multirow[b]{2}{*}{ Variabel } & \multicolumn{2}{|c|}{ Kelompok } & \multirow[b]{2}{*}{ Nilai $\mathbf{P}$} \\
\hline & $\begin{array}{c}\text { Ovari } \\
N=5\end{array}$ & $\begin{array}{c}\text { Ovari } \\
+ \text { Zink } \\
\mathrm{N}=5\end{array}$ & \\
\hline \multicolumn{3}{|c|}{ Pengambilan ke-2 } & 0,627 \\
\hline Mean \pm STD & $7,16 \pm 2,177$ & $6,57 \pm 1,421$ & \\
\hline Median & 6,251 & 6,371 & \\
\hline Range & $4,96-10,39$ & $4,88-8,78$ & \\
\hline \multicolumn{3}{|c|}{ Pengambilan ke-3 } & $0,049 *$ \\
\hline Mean \pm STD & $8,25 \pm 2,452$ & $5,54 \pm 0,904$ & \\
\hline Median & 8,083 & 5,751 & \\
\hline Range & $5,75-12,24$ & $4,24-6,61$ & \\
\hline
\end{tabular}

\begin{tabular}{|c|c|c|c|}
\hline \multirow[b]{2}{*}{ Variabel } & \multicolumn{2}{|c|}{ Kelompok } & \multirow[b]{2}{*}{ Nilai $\mathbf{P}$} \\
\hline & $\begin{array}{l}\text { Ovari } \\
N=5\end{array}$ & $\begin{array}{c}\text { Ovari+Zink+Rise } \\
N=5\end{array}$ & \\
\hline \multicolumn{3}{|c|}{ Pengambilan ke-2 } & 0,541 \\
\hline Mean \pm STD & $7,16 \pm 2,177$ & $6,44 \pm 1,281$ & \\
\hline Median & 6,251 & 6,748 & \\
\hline Range & $4,96-10,39$ & $4,51-7,98$ & \\
\hline \multicolumn{3}{|c|}{ Pengambilan ke-3 } & $0,016 *$ \\
\hline Mean \pm STD & $8,25 \pm 2,452$ & $4,59 \pm 1,145$ & \\
\hline Median & 8,083 & 4,167 & \\
\hline Range & $5,75-12,24$ & $3,68-6,57$ & \\
\hline
\end{tabular}

\begin{tabular}{|c|c|c|c|}
\hline \multirow[b]{2}{*}{ Variabel } & \multicolumn{2}{|c|}{ Kelompok } & \multirow[b]{2}{*}{ Nilai $\mathbf{P}$} \\
\hline & $\begin{array}{l}\text { Ovari } \\
N=5\end{array}$ & $\begin{array}{c}\text { Ovari } \\
\text { +Rise } \\
\mathrm{N}=5\end{array}$ & \\
\hline \multicolumn{3}{|c|}{ Pengambilan ke-2 } & $\mathbf{0 , 7 3 7}$ \\
\hline Mean \pm STD & $7,16 \pm 2,177$ & $6,74 \pm 1,525$ & \\
\hline Median & 6,251 & 6,367 & \\
\hline $\begin{array}{l}\text { Range (min- } \\
\operatorname{max)}\end{array}$ & $4,96-10,39$ & $4,94-9,13$ & \\
\hline \multicolumn{3}{|c|}{ Pengambilan ke-3 } & 0,164 \\
\hline Mean \pm STD & $8,25 \pm 2,452$ & $6,28 \pm 1,513$ & \\
\hline Median & 8,083 & 5,921 & \\
\hline Range & $5,75-12,24$ & $4,64-8,41$ & \\
\hline
\end{tabular}
yang signifikan atau tidak bermakna secara statistik (Tabel 3).

Pada penelitian ini, digunakan tikus galur Wistar betina yang berumur lebih dari 9 minggu. Hal ini dikarenakan. tikus telah mengalami kematangan secara seksual, 


\section{Artikel Penelitian}

Vol 7 No. 2, Oktober 2018

ISSN 2460-8742

http://journal.unair.ac.id/ORTHO@journal-orthopaedi-and-traumatology-surabaya-media-104.htmI

namun kematangan tulang baru didapatkan setelah usia 10 bulan, sehingga low peak bone mass dapat dicapai. Pembuatan model tikus osteoporosis dicapai melalui tindakan ovariektomi dan pemberian dexametasone injeksi. Hal ini sesuai dengan penelitian sebelumnya yang dilakukan oleh Jiang et al dan Govindarajan et al yang menjelaskan bahwa tindakan ovariektomi dan pemberian dexametasone memberikan efek osteoporosis lebih besar dan lebih cepat, dibandingkan hanya tindakan ovariektomi atau pemberian dexametasone saja. Hal ini disebabkan oleh efek kombinasi antara penurunan formasi tulang dan peningkatan resorpsi tulang akibat defisiensi estrogen dan glucocorticoid induce osteoporosis. Adanya peningkatan ekspresi $\beta$-Crosslap pada pengambilan ke-2 dibandingkan pengambilan ke-1, menunjukkan keberhasilan proses pembuatan tikus model osteoporosis. Hal ini sesuai dengan penelitian sebelumnya yang dilakukan oleh Jiang et al dan Govindarajan et al yang menjelaskan bahwa tindakan ovariektomi dan pemberian dexametasone memberikan efek osteoporosis lebih besar dan lebih cepat. $^{12-15}$

Uji One Way Anova pada pengambilan ke-3 didapatkan nilai $\mathrm{p}=$ $0,024(\mathrm{p}<0,05)$ yang berarti signifikan atau bermakna secara statistik Hasil ini menunjukkan keberhasilan bahwa terdapat hubungan yang bermakna antara proses tikus sebagai model hewan osteopororsis dengan terapi yang diberikan (Zink dan/atau Risedronate) pada semua sampel penelitian. Hasil ini sesuai dengan penelitian sebelumnya yang menyatakan bahwa Zink dan/atau Risedronate memiliki keberhasilan dalam terapi osteoporosis. ${ }^{4-8}$

Hasil bermakna ditunjukkan pada kelompok yang diberikan Zink saja dan kombinasi antara Zink+Risedronate. Hal ini sesuai dengan penelitian sebelumnya yang dilakukan oleh Molokwu et al dan Yamaguchi et al yang menunjukkan bahwa pemberian zink oral terhadap hewan model osteoporosis memiliki efek potensial terhadap proses osteogenik, yaitu menstimulasi formasi tulang oleh osteoblas, sekaligus menekan resorpsi tulang oleh osteoklas. $^{3,7,8}$ Selain itu, terdapat pula penelitian yang memanfaatkan Risedronate sebagai carrier untuk Zinc-Hydroxyapatite nanoparticles. Hal ini dikarenakan, tingginya afinitas Risedronate terhadap tulang, sehingga memungkinkan ZincHydroxyapatite nanoparticles untuk dapat bekerja secara optimal dalam mengembalikan struktur mikroarsitektur tulang. Penambahan Zink terhadap Risedronate mampu meningkatkan onset kerja Risedronate terhadap tulang. ${ }^{17}$

Sedangkan, tidak adanya kemaknaan pada kelompok yang diberikan 
Artikel Penelitian

Vol 7 No. 2, Oktober 2018

ISSN 2460-8742

http://journal.unair.ac.id/ORTHO@journal-orthopaedi-and-traumatology-surabaya-media-104.htmI

Risedronate saja dapat diakibatkan waktu pemberian yang terlalu singkat yaitu, 30 hari atau $4 \mathrm{x}$ pemberian. Padahal onset Risedronate agar memulai efek anti resorptif yaitu minimal $6-12$ bulan. $^{4-6}$

\section{KESIMPULAN DAN SARAN}

Berdasarkan penelitian ini, Zink mampu menurunkan bone turnover pada tikus model osteoporosis. Hal ini ditunjukkan dengan menurunnya ekspresi $\beta$-CrossLap. Hasil yang lebih baik bahkan ditunjukkan ketika Zink dikombinasikan dengan Risedronate.

Perlu dilakukan penelitian lebih lanjut dan dengan durasi yang lebih lama untuk mengetahui efek jangka panjang terhadap pemberian oral Zink dan/atau Risedronate. Selain itu, perlu adanya penelitian terhadap manusia sebelum temuan ini dapat digunakan secara luas sebagai terapi pada osteoporosis.

\section{REFERENSI}

1. Noor Z, Kania N, Setiawan B. Tibia Bone Properties at Different Time Course of Ovariectomized Rats. Journal of Diabetes \& Metabolic Disorder. 2014;13(91): 1-7

2. Mithal A, Ebeling P. The Asia-Pacific Regional Audit. Epidemiology, cost and burden of Osteoporosis in 2013. International Osteoporosis Foundation. 2015; 56-60

3. Gurban CV, Mederle O. The OPG/RANKL System and Zinc Ions are Promoters of Bone Remodeling by $\begin{array}{lrl}\text { Osteoblast } & \text { Proliferation in } \\ \text { Postmenopausal } & \text { Osteoporosi }\end{array}$ Department of Biochemistry, University of Medicine and Pharmacy, Timisoara. Rom J Morphol Embryol. 2011, 52(3 Suppl):1113-1119

4. Watts NB, Camacho PM, Harris ST, Kleerekoper M. American Association of Clinical Endocrinologist Medical Guidelines for Clinical Practice For The Diagnosis and Treatment of Postmenopausal Osteoporosis. AACE Guidelines. Endocrine Practice Vol 16 (Suppl 3). 2010; 5-14

5. Nuti R. Updates on Mechanism of Action and Clincal Efficacy on Risedronate in Osteoporosis. Medical and Surgical Science and Neuroscience Department. University of Siena. Clinical Cases in Mineral and Bone Metabolism. 2014; 11(3): 208-214

6. Lolascon G, Sirico F, Ferrante A. Risedronate's Efficacy. From Randomized Clinical Trial to Real Clinical Practice. Department of Orthopaedics and Rehabilitation Medicine. University of Naples. Clinical Cases in Mineral and Bone Metabolism. 2010; 7(1): 19-22

7. Yamaguchi M. Osteoporosis Treatment with New Osteogenic Factors. Department of Hematology and Medical Oncology, Emory University School of Medicine. J Mol Genet Med. 2013; 7: 2

8. Yamaguchi M. New Development in Osteoporosis Treatment. The Synergistical Osteogenic Effects with Vitamin D3, Menaquinone-7, Genistein and Zinc. Vitam Miner 2013; S6-e001

9. Puspitawati I, Windarwati, Sukorini U, Herowati P, Prabowo A. Kadar CTX Perempuan Osteoporosis Lebih Tinggi Daripada Perempuan Normal dan Osteopenia. Indonesian Jurnal of Clinical Pathology and Medical Laboratory. 2013; Vol.19,No. 3: 161166

10. Lee J, Vasikaran S. Current Recommendations for Laboratory 
Artikel Penelitian

Vol 7 No. 2, Oktober 2018

http://journal.unair.ac.id/ORTHO@journal-orthopaedi-and-traumatology-surabaya-media-104.html

Testing and Use of Bone Turnover Markers in Management of Osteoporosis. Department of Core Clinical Pathology and Biochemistry. PathWest-Royal Perth Hospital. Ann Lab Med. 2012; 2: 105-112

11. Arslan M, Cogendez E, Eken M, Arioglu PF, Eren S. Serum Beta Crosslaps as a Predictor for Osteoporosis in Postmenopausal Women. Zeynep Kamil Education and Research Hospital, Obstetric and Gynecology Department. Istanbul, Turkey. 2015; 78 (2): 36-40

12. Govindarajan P, Khassawna T, Kampschulte M. Implication of Combined Ovariectomy and Glucocorticoid (dexamethasone) Treatment on Mineral, Microarchitectural, Biomechanical and Matrix Properties of rat bone. Laboratory of Experimental Trauma Surgery. Int. J. Exp. Path. 2013; 94: 387-398

13. Yao W, Cheng Z, Pham A. Glucocorticoid-Induced Bone Loss in Mice Can Be Reversed by the Actions of Parathyroid Hormone and Risedronate on Different Pathways for Bone Formation and Mineralization. Arthritis and Rheumatism. American Collage of Rheumatology. 2008; Vol.58,No.11: 3485-3497

14. Lelovas $P$, Xanthos $T$, Thoma SE, Lyritis GP. The Laboratory Rat as an Animal Model for Osteoporosis Research. American Association for Laboratory Animal Science. 2008; Vol 58,No.5: 424-430.

15. Ren H, Liang D, Shen G, Yao Z, Jiang $X$. Effects of Combined Ovariectomy with Dexamethasone on Rat Lumbar Vertebrae. Menopause: The Journal of The North American Society. 2015; Vol.23.No.4: 441-450.

16. Abbexa Ltd. Rat beta Crosslaps (bCTx) ELISA Kit. Cambridge Science Park. 2017. Cat. No. abx256110
17. Khajuria DK, Disha C, Vasireddi R, Mahapatra R. Risedronate/ZincHydroxyapatite Base Nanomedicine for Osteoporosis. Material Science and Engineering. 2016; Vol.63: 78-87. 